ISSN 1991- 8690

Website: http://jsci.utq.edu.iq
1991 - الترقيم الدولي

Email: utjsci@utq.edu.iq

\title{
Prevalence Of Urinary Tract Infections In Diabetic Patients, Case-Control Study
}

Kadhim mohan manhil Al-majedy

Thi-Qar University . Collage Of Medicine. Al-Hussain Teaching Hospital

E-mail:kadhimmohan@yahoo.com

\begin{abstract}
$\underline{\text { Abstract }}$
There is evidence that patients with diabetes have an increased risk of asymptomatic bacteriuria and urinary tract infections (UTIs). UTI is the most common bacterial infection in diabetic patient.The aim of this study was to assess the prevalence of UTIs among diabetic patients and to identify the frequent of asymptomatic bacteriuria among diabetic subjects in compared with non-diabetic subject. The study population include 300 subjects .one-hundred and fifty patients with diabetes ( 84 female and 66 male) as a test group and 150 patients with non- diabetes mellitus ( 80 female and 70 male) as a control group. Between July 2012 - October2013.300 diabetic and non diabetic urine samples were collected All urine samples were processed in the lab. following standard laboratory protocol we collected patients' personal history data.. The prevalence of UTI was $50.7 \%$ in diabetic patients and $10 \%$ in non-diabetic subjects .there was significant difference in the effect of gender in both diabetic (62\% female and $36 \%$ male had UTI) and non-diabetic ( $14 \%$ female and $7 \%$ male had UTI).there was significant increase asymptomatic bacteriuria in women within diabetic group (80\% female and 62\% male were asymptomatic)The frequency of UTI increase with diabetic by fourfold in comparison to that of non-diabetic subjects. the women had increased frequency of UTI more in diabetic patients than women in non-diabetic and most of them asymptomatic. The statistical significance of an association between two variables was assessed by Chi-square $\left(\mathrm{X}^{2}\right)$ test of independence.
\end{abstract}

Key words: patients, diabetes, urinary tract infection.

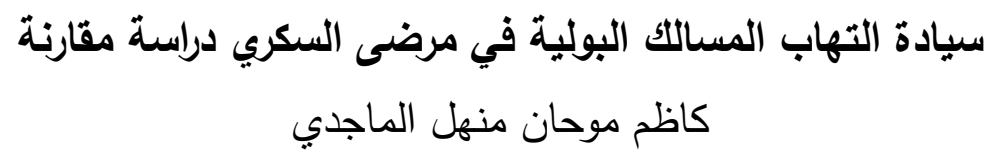

الخلاصة

تشير كل الدلائل بان مرضى السكري أكثر عرضة لإصابة بالتهاب المسالك البولية وعادة يكون الالتهاب غير مصحوب بإعراض سريريه،وان نسبة الإصابة بالتهاب المسالك البولية لدى النساء المصابات بداء السكري تكون أكثر من الرجال .وان الهدف من هذه الدراسة هو تقيم ومعرفة سيادة التهاب المسالك

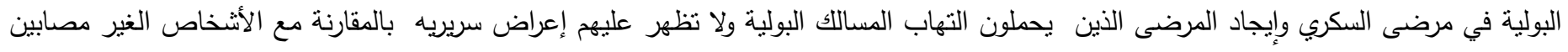
بمرض السكري .حيث شملت هذه الدراسة 300 شخص منهم 150 شخص مصاب بداء السكري (85 امرأة و66 رجل) بالمقارنة مع مجموعة السيطرة والتي شملت 150 شخص غير مصابين بمرض السكري(80 امرأة و 70 رجل) ،وكانت فترة الدراسة من شهر نبسان 2012-إلى شهر نترين الأول 2013 وقد أخذت عينات الإدرار لكل المرضى وفحصت في المختبر لمعرفة حالات الالتهاب المسالك البولية وكانت النتائج تثنير إلى إن نسبة الإصابة بالالتهاب

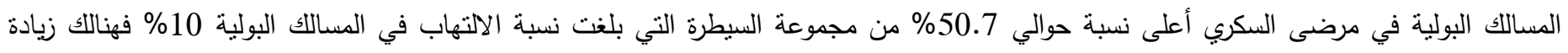

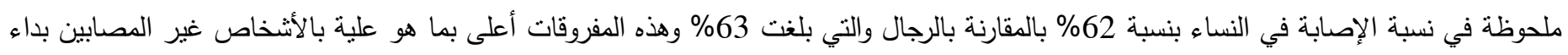

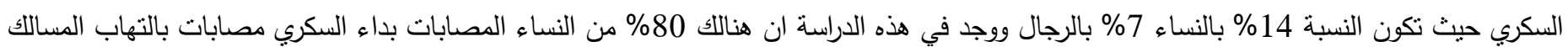

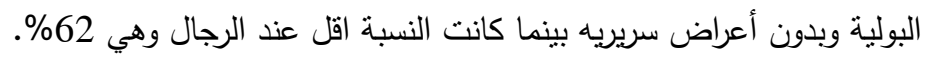
الكلمات المفتاحية : المرضى، داء السكري،التهاب المسالك البولية . 


\section{Introduction}

Urinary tract infections (UTIs) are the frequent infections observed in clinical practice and results in a significant morbidity and high medical costs. UTI is a common infection observed in diabetic patients. DM alters the genitourinary system where UTI can be a cause of severe complications ranging from dysuria (pain or burning sensation during Urination) organ damage and sometimes even death due to complicated UTI (pyeleonephritis) ${ }^{(27)}$.Diabetes results in several abnormalities of the host defense system that might result in a higher risk of certain infections. These abnormalities include immunologic impairments, such as impaired migration, intracellular killing, phagocytosis, and chemotaxis in polymorphonuclear leukocytes from diabetic patients and local complications related to neuropathy, such as impaired bladder emptying .Also, higher glucose concentration in urine may serve as a culture medium for pathogenic microorganisms $\left.{ }^{(12}\right)$. The most common cause of UTI in men and women with and without DM is E. coli. Some reports have noted that a lower proportion of UTIs is caused by this organism in diabetic patients as compared with age-matched non diabetic patients $(18,24,4)$ Antimicrobial resistance among uropathogens causing community and hospital acquired urinary tract infections is increasing (13)Few data are available on the role of DM itself as a risk factor for the development of antimicrobial resistance of the uropathogens(11) Asymptomatic bacteriuria, acute pyeleonephritis and the complications of UTI are reported to be more common in patients with diabetes, and over 100 studies support these observations. During the course of a lifetime with diabetes, UTIs would be ranked among the top ten concurrent or complicating illnesses by most experts and patients (1)Frequent reviews on UTI and diabetes are featured in both the diabetes and UTI literature(30,10)In more than 20 studies, asymptomatic bacteriuria has been reported to be more common in women with diabetes (16)The data in men are less convincing(16)Prospective studies to determine the natural history of asymptomatic bacteriuria in patients with diabetes and the evidence that asymptomatic bacteriuria should be pursued and treated is lacking for all population groups other than pregnant women $[17,15)$ However, in a recent study, the increased risk of symptom development has been identified((28)Of 52 women randomized to no treatment, 27 episodes of pyeleonephritis occurred among women with diabetes and asymptomatic bacteriuria occurred (0.6 episodes per 1000 patient days), and this was significantly more than the one episode among patients whose asymptomatic infections were treated(20)In this study we screen in our society the prevalence of urinary tract infections in diabetic subjects in compared to that of non-diabetic group also to know the frequency of subclinical and asymptomatic urinary tract infections within the diabetic persons in compared with control group and study the effect of gender in both cases and control group. The aims of this study were to assess the prevalence of UTIs among diabetic patients . and to identify the frequent of asymptomatic bacteriuria among diabetic subjects in compared with non-diabetic subject.

\section{Patients and Method}

In this study the diabetic patients were selected patients from those attended the Al-Nasria diabetic center while the control group collected from patients visited the Al-Hussein teaching hospital .The study performed from July 2012-october 2013.The study population include 300 subjects .one-hundred and fifty patients with diabetes ( 84 female and 66 male) as a test group and 150 patients with no diabetes mellitus (80 female and 70 male) as a control group.both the case and control group were marched in gender and age .All subjects in the test group were fulfilled the WHO criteria of diabetes mellitus.

The WHO criteria for diagnosis of diabetes mellitus. 1 -symptoms of diabetes plus random blood glucose concentration $\geq 200 \mathrm{mg} / \mathrm{dl}$.

2.fasting plasma glucose $\geq 126 \mathrm{mg} / \mathrm{dl}$.

3.two-hours plasma glucose $\geq 200 \mathrm{mg} / \mathrm{dl}$ during the oral glucose tolerance test.

The control group included individuals who did not have history of diabetes mellitus and any symptoms or sign of diabetes mellitus and blood samples were taken for measurement of fasting blood sugar and persons with FBS $>126 \mathrm{mg} / \mathrm{dl}$ were excluded from the study.

Individuals in both case and control groups were asked about any symptoms and signs of urinary tract infections (dysuria, urgency, frequency or suprapubic pain or tenderness) with or without fever at presentation or during hospitalization.Urine was collected in sterile uricols as clean-catch midstream samples general urine examination, microbial estimation and quantitative bacterial culture of a urine specimen was performed by inoculating culture media. The identification of germs was based on colonial appearance and biochemical characteristics. 
Significant bacteriuria was defined as the presence of $\geq 105$ colony forming units (CFU) per milliliter of urine.. Generally, more than $100,000 / \mathrm{ml}$ of microorganism reflects significant bacteriuria. Multiple organisms reflect contamination were excluded from study.A symptomatic urinary tract infection was defined as the presence of bacteriuria in a patient with fever or urinary symptoms Asymptomatic bacteriuria (ASB) was defined as bacteriuria without fever or urinary symptoms.The statistical significance of an association between two variables was assessed by Chisquare $\left(\mathrm{X}^{2}\right)$ test of independence.An estimate was statically significant if its calculated value was less than $\mathrm{P}<0.05$ level of significance with $95 \%$ confidence.

\section{Results}

Figure 1):shows the prevalence of urinary tract infections in diabetic subjects is more frequent than in non-diabetic persons. It is $50.7 \%$ in the diabetic subjects compared to only $10 \%$ in non-diabetic subjects There is a very high significant epidemiological association ( $p$-value <0.05)(table1).Figure 2): shows that the urinary tract infections frequency in diabetic subjects was significantly increased in diabetic women $(61.9 \%)$ in comparison to that of males $(36.4 \%)$ (pvalue 0.05).(table). Figure 3):shows that the frequency of urinary tract infections was not significantly associated with gender ( $\mathrm{p}=\mathrm{value}>0.05)$.(table 3 ). Figure4):show that most of diabetic women were asymptomatic $(80 \%$ vs $19.2 \%)$ in comparison to that of diabetic male $(62.5 \%$ vs $37 \%)$ with significantly associated (p-value $<0.05)($ table4).Figure 5):show a mild difference between diabetic and non-diabetic subjects regarding urinary tract infections were symptomatic or not (sympt. UTI $25 \%$ in diabetic Vs $46.6 \%$ in non-diabetic) while (asymptomatic UTI 75\% in diabetic vs $53.3 \%$ in non-diabetic) (p-value $>0.05)($ table 5).

Table (1) The frequency of UTI in diabetic and Nondiabetic subjects

\begin{tabular}{|l|l|l|l|l|}
\hline & Diabetic & Non-diabetic & Total & \multirow{2}{*}{$\mathrm{X}^{2=9.243}$} \\
\cline { 1 - 4 } With UTI & $76(50.7 \%)$ & $15(10 \%)$ & 91 & $\begin{array}{c}\text { p. valve } \\
<0.05\end{array}$ \\
\cline { 1 - 4 } Without UTI & $74(49.3 \%)$ & $135(90 \%)$ & 209 & \\
\cline { 1 - 4 } Total & 150 & 150 & 300 & \\
\hline
\end{tabular}

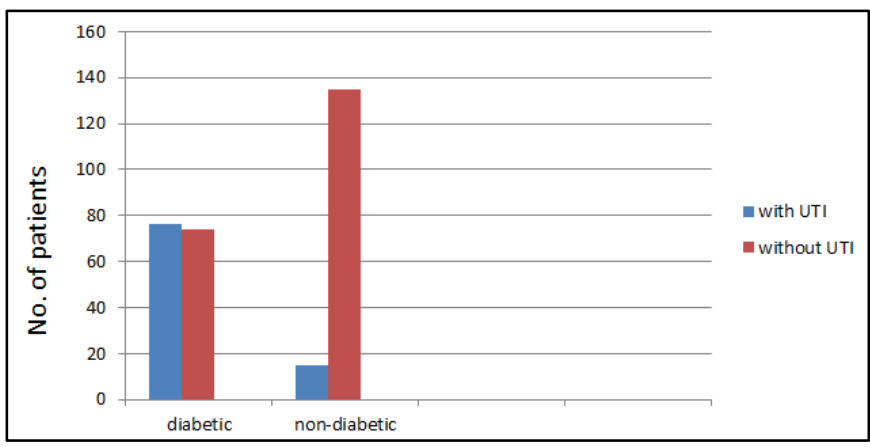

Figure 1: the distribution of UTI in diabetic and nondiabetic subjects

(Table 2) Distribution of UTI by gender in diabetic subjects

\begin{tabular}{|c|c|c|c|c|}
\hline \multicolumn{3}{|c|}{ Diabetic } & & \multirow[b]{2}{*}{$X^{2}=9.6$} \\
\hline gender & No. with UTI & $\begin{array}{c}\text { No. without } \\
\text { UTI }\end{array}$ & $\begin{array}{c}\text { Total } \\
\text { no. }\end{array}$ & \\
\hline women & $52(61.9 \%)$ & $32(38.1 \%)$ & 84 & \multirow{2}{*}{$\begin{array}{c}\text { p. valve } \\
0.05<\end{array}$} \\
\hline Men & $24(36.4 \%)$ & $42(63.6 \%)$ & 66 & \\
\hline
\end{tabular}

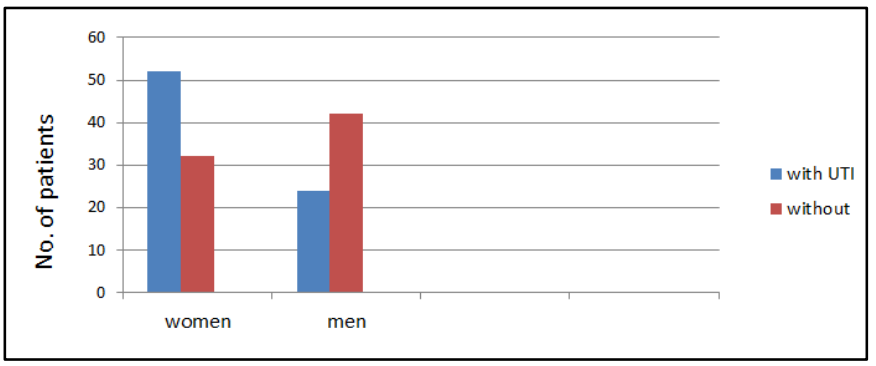

Figure 2: the distribution of UTI by gender in diabetic subjects

(Table3) Distribution of UTI by gender in non- diabetic subjects

\begin{tabular}{|c|c|c|c|c|}
\hline \multicolumn{4}{|c|}{ Non-diabetic } & \multirow{3}{*}{$\begin{array}{c}\mathrm{X}^{2}=2.4 \\
\mathrm{p} \text { - value } \\
>0.05\end{array}$} \\
\hline gender & $\begin{array}{c}\text { No. with } \\
\text { UTI }\end{array}$ & No. without UTI & $\begin{array}{l}\text { Total } \\
\text { No. }\end{array}$ & \\
\hline Women & 11(13.8\%) & $69(86.2 \%)$ & 80 & \\
\hline Men & $4(5.7 \%)$ & $66(94.3 \%)$ & 70 & \\
\hline
\end{tabular}




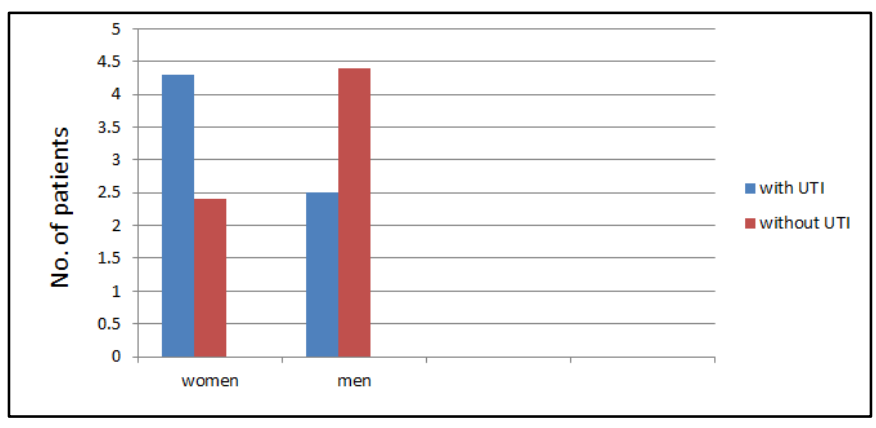

(Figure 3) the distribution of UTI by gender in nondiabetic subjects

(Table 4) Distribution of UTI by symptom of UTI and gender within diabetic subjects

\begin{tabular}{|c|c|c|l|}
\hline & Women & Men & \multirow{2}{*}{$\begin{array}{l}\text { 2 }=3.6 \\
\text { P-value }<0.05\end{array}$} \\
\cline { 1 - 3 } Sympt. UTI & $10(19.2 \%)$ & $9(37.5 \%)$ & \\
\hline ASB & $42(80.8 \%)$ & $15(62.5 \%)$ & \\
\hline Total no. & 52 & 24 & \\
\hline
\end{tabular}

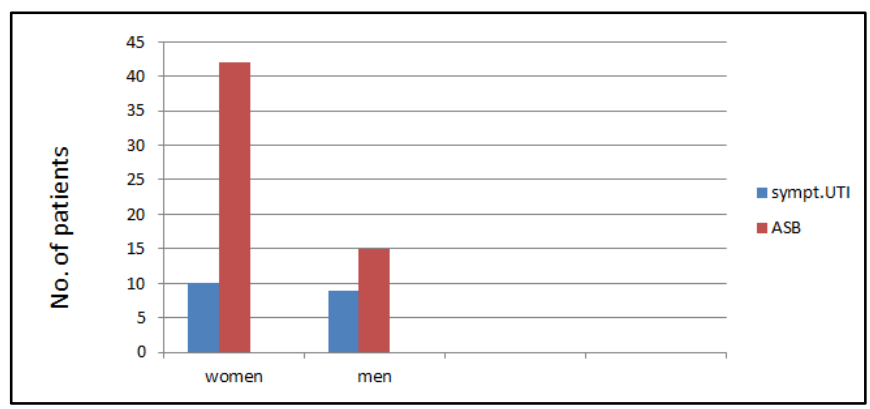

(Figure4) the distribution of UTI by symptom of UTI and gender within diabetic subjects

(Table 5) Distribution of UTI by symptoms of UTI in both diabetic and non-diabetic subjects

\begin{tabular}{|l|c|c|c|}
\cline { 2 - 3 } \multicolumn{1}{l|}{} & Diabetic & Non-diabetic & \multirow{2}{*}{$\begin{array}{c}X^{2}=1.5 \\
\text { p-value } \\
>0.05\end{array}$} \\
\hline Sympt.UTI & $19(25 \%)$ & $7(46.6 \%)$ & \\
\cline { 1 - 3 } ASB & $57(75 \%)$ & $8(53.3 \%)$ & \\
\cline { 1 - 3 } total & 76 & 15 & \\
\hline
\end{tabular}

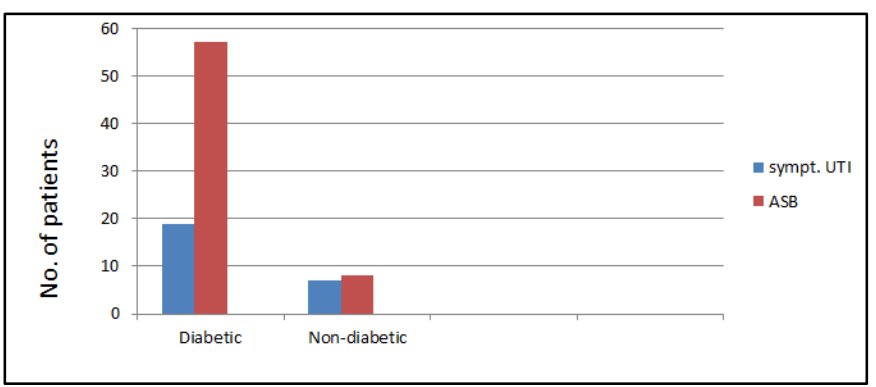

(Figure5) the distribution of UTI by symptoms of UTI in both diabetic and non-diabetic subjects

\section{Discussions}

The idea behind this study is to find the frequency of urinary tract infections in diabetic subjects in comparison to that of control group and to examine the prevalence of subclinical(asymptomatic) urinary tract infections within the diabetic group in comparison to non-diabetic persons.Our study shows that increased frequency of urinary tract infection in diabetic subjects was $(50.7 \%)$ in comparison to control (non-diabetic subjects $(10 \%)$. These results were agreement with other studies, Teodora Chita. et $\mathrm{al}^{(2)}$ show that From the total number1470 of patients, 158 had positive urine cultures, meaning $10.7 \%$. Out of the total number of 158 UTIs, 124 (78.4\%) were asymptomatic bacteriuria.other study Mehvish Saleem.et al ${ }^{(1)}$ show that Prevalence of UTI in the lower socioeconomic status in 1000 diabetic and non diabetic subjects was $56.4 \%$ and 43.6\%. UTI in higher socioeconomic status was $51.6 \%$ and $48.4 \%$. In our study, $60.9 \%$ of diabetic women developed an UTI, result that is differ from other studies like one obtained by Gearing's and coworkers (29) who found a prevalence of $20 \%$ in women and other obtained by Mehvish Saleem(1)was revealed that $15.3 \%$ of diabetic women had urinary tract infections. But this study agreement with Teodora Chiţă ,Monica Licker(2)show that prevalence of $56.4 \%$ in women with diabetes mellitus .Our study shows that the prevalence of UTI in diabetic patients is twofold higher in women than in men. This important difference can be explained by a variety of men-related factors, such as the greater length of the urethra, the greater distance between the urogenital meatus and the anus, and the antibacterial properties of the prostatic fluid but these differences were increased in diabetic subjects than non-diabetic group.This study show the frequency of asymptomatic bacteriuria increased in diabetic women than nondiabetic one that similar to study MARJO RENKO ${ }^{(30)}$ show that ASB was more common both in patients with 
type 1 diabetes (odds ratio 3.0 [95\% CI 1.1-8.0]) and type 2 diabetes $(3.2[2.0-5.2])$ than in control subjects.

\section{Conclusion}

1)-T he prevalence of urinary tract infections were increased in diabetic subjects fourfold $(50.7 \%)$ in comparison to that in non-diabetic group (10\%).

2)-T here is significant increase in frequency of urinary tract infections within diabetic women and most of them were asymptomatic.

3)-There is a mild difference in frequency of symptoms of urinary tract infections between diabetic subjects and control group and this difference was statistically not significant (p.value $>0.05$ )

\section{Reference}

1.American Diabetes Association. Position statement. Standards of medical care in diabetes 2012.

2.Brauner A, Flodin U, Hylander B, Ostenson $\mathrm{C}$ : Bacteriuria, bacterial virulence and host factors in diabetic patients.Diabet Med 1993, 10:550-554

3.Bonadio M, Meini M, Spitaleri PGigli C: Current microbiological and clinical aspects of urinary tract infections.

4.Bonadio M, Meini M, Gigli C, Longo B, Vigna A. Urinary tract infection in diabetic patients. Urol Int 1999;63:215-9.

5. Diabetic care 22-1785-1789.1999. Diabetes and Urinary Tract Infections: The Case Against a Preemptive Strike.

6.Edward J. Boyko, , Stephan D. Fihn, Diabetes and the Risk of Acute Urinary Tract Infection Among Postmenopausal Women .Diabetes Care October 2002 vol. 25 no. 10 1778-1783.

7. Greenlings SE, Stolk RP, Camps MJ et al. Risk factors for symptomatic urinary tract infection in women with diabetes. Diabetes Care 23: 17371741, 2000.

8. Hosking DJ, Bennett T, Hampton JR: Diabetic autonomic neuropathy. Diabetes Care27:10431054, 1978.
9.Hoepelman IM. Urinary tract infection in patients with diabetes mellitus. Int $\mathbf{J}$ Antimicrob Agents 1994;4:113-6.

10.International Diabetes Federation. IDF Diabetes Atlas, 5th edition Update, 2012.

11. Kees J Gortera, ${ }^{*}$, Eelko Hakb,eta. Risk of recurrent acute lower urinary tract infections and prescription pattern of antibiotics in women with and without diabetes in primary care. Family Practice 2010; 27:379-385.

\section{EurUrol 2001, 40(4):43944. PubMed Abstract}

13.Lye WC, Chan RK, Lee EJ, Kumarasinghe G: Urinary tract infections in patients with diabetes mellitus. J Infect 1992, 24:169-174

14.Mehvish Saleem, Betty Daniel. Prevalence of Urinary Tract Infection among Patients with Diabetes in Bangalore CityInt. J. Emerg. Sci., 133142, June 2011.

15.MARJO RENKO, Meta-Analysis of the Significance of Asymptomatic Bacteriuria in Diabetes Diabetes Care 34:230-235, 2011

16. Patterson JE, Andriole VT: Bacterial urinary tract infections in diabetes. Infect Dis Clin North Am 11:735-750, 1997.

17.Patterson JE, Andriole VT: Bacterial urinary tract infections in diabetes. Infect Dis Clin North Am 1995, 9:25-51.

18.Patterson JE, Andriole VT. Bacterial urinary tract infections in diabetes. Infect Dis Clin N Am 1997;11:735-50.

19.Patterson JE, Andriole VT. Bacterial urinary infections in diabetes. Infect Dis Clin N Am $1995 ; 1: 25$

20.Robbins SC, Tucker AW. The cause of death in diabetes. New

Engl J Med 1944;231:865-8.

21.. Rom J Diabetes Nutr Metab Dis. 20(2):099-105 doi: 1020.2478/rjdnmd-2013-0012 
22.Semethkowska-Jurkiewicz E, Horoszek-Maziarz S, Galinski J, Manitius A, Krupa-Wojciechowska B. The clinical course of untreated asymptomatic bacteriuria in diabetic patients - 14 year followup. Mater Med Pol 1995;27:91-5.

23.Teodora Chiţă ,Monica Licker, Alexandra Sima , etal. Prevalence of urinary tract infection in diabetic patients . Rom J Diabetes Nutr Metab Dis. 20(2):099-105 doi: 10.2478/rjdnmd-2013-0012

24.US Renal Data System. USRDS 2004 Annual Data Report. The National Institutes of Health, National Institute of Diabetes and Digestive and Kidney Diseases, Bethesda, 2004.

25. Viberti GC, Walker JD, Pinto J: Diabetic nephropathy. In International Textbook of Diabetes Mellitus. Vol. 2. Alberti KGMM, DeFronzo RA, Keen H, Zimmet P, Eds. New York, John Wiley \& Sons, 1992, p. 1301-1302

26. Valerius NH, Eff C, Hansen NE, Karle H, Nerup J, Soeberg B, Sorenson SF: Neutrophil and lymphocyte function in patients with diabetes mellitus. Acta Med Scand211:463-467, 1982

27.World Health Organization. WHO The top 10 causes of death. Fact sheet Nr. 310. Updated June2011

28.Zhanel GG, Harding GKM, Nicolle LE. Asymptomatic bacteriuria in patients with diabetes mellitus. Rev Infect Dis

1991;3:150-4.

29.Zhanel G.G., Nicolle L.E., Harding G.K.M., Untreated asymptomatic bacteriuria (ABU) in women with diabetes mellitus(WWDM) is associated with high rates of pyeleonephritis (P). Presented at the 39th Interscience Conference on Antimicrobial Agents and Chemotherapy, San Francisco, California, 26 September, 1999.

30.. Zimmet P. Alberti KG, Shaw J. Global and Societal implications of the diabetes epidemic. Nature414: 782-787, 2001 